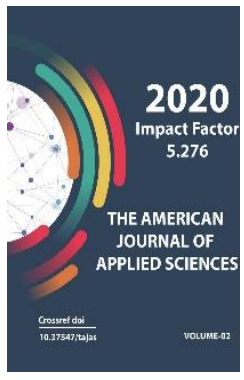

Copyright: Original content from this work may be used under the terms of the creative commons attributes 4.0 licence.

\section{Ensuring Energy Efficiency Of Air Permeability Of Interfloor Ceilings In The Sections Of Nodal Connections}

\author{
Sadriddin Sayfiddinov \\ Professor, Tashkent Institute Of Architecture And Civil Engineering, Tashkent, Uzbekistan \\ Ulugbek Solijonovich Akhmadiyorov \\ Associate Professor, Tashkent Institute Of Architecture And Civil Engineering, Tashkent, \\ Uzbekistan \\ Nurmukhammadkhon Saidmaksud Ugli Razzokov \\ Doctoral Student Of The Department Of "Buildings And Structures", Tashkent Institute of \\ Architecture And Civil Engineering, Tashkent, Uzbekistan \\ Pakhriddin Sayfiddinovich Akhmedov \\ Senior Lecturer, Namangan Engineering And Construction Institute, Namangan, Uzbekistan
}

\title{
ABSTRACT
}

This research paper discusses the provision of energy efficiency for air permeability of interfloor ceilings in the sections of nodal connections. Resistance to air permeability is the possibility of using the proposed method of device thermal liners, which accordingly increase the durability of the building.

\section{KEYWORDS}

Provision, energy efficiency, air permeability, interfloor floors, sections, nodal connections.

\section{INTRODUCTION}

Provision, energy efficiency, air permeability, interfloor floors, sections, nodal connections.

The value of hardness is estimated by the value of the relative deflection, which is equal to the ratio of the absolute deflection to the span. Its value should not exceed $1 / 250$ for interfloor.

Particular attention should be paid to the design of the floor at the points of abutment to the bearing walls, since cold bridges may form 
in the walls, which will lead to uncomfortable operating conditions at home.

The slabs must also meet the requirements that correspond to the class of the house.

The outer surface requires special attention, which must be additionally insulated by means of a special constructive recess. One should bear in mind the existing thermo physical problem in the form of runoff phenomena, when an increased heat transfer is observed at the junction of materials with a sharp difference in thermal conductivity values. It is possible to prevent excessive heat loss by using additional thermal liners, geometric dimensions and thermal conductivity of which are selected by a special calculation.

\section{METHODS OF RESEARCH}

Depending on the purpose of the premises up to the floors, special requirements may also be put forward: water tightness. Regardless of the location of the ceiling in the building, its constructive solution must be economically and technologically sound.

The main purpose of energy efficiency in buildings is to increase the resistance to air infiltration through the junction of the floor structure with the wall. Although there is a utilitarian use associated with ensuring the mechanical strength of the joint between the filling box and the load-bearing wall.

Providing resistance to air permeability in the form of a requirement $R_{g} \geq R_{g n}$ is a well-known normative rule and in this context is considered to confirm the possibility of using the proposed method of device thermal liners.

The required resistance to air permeability $\mathrm{R}_{\mathrm{gn}}, \mathrm{m}^{2} \mathrm{hPa} / \mathrm{kg}$ is determined by the formula:

$$
\mathrm{R}_{\mathrm{gn}}=\Delta \mathrm{P} / \mathrm{G}_{\mathrm{n}}
$$

where, $\mathrm{GH}_{\mathrm{H}}$ - permissible air permeability, for interfloor crossings is taken $G_{n}=0,5 \mathrm{kr} / \mathrm{m}^{2}$ year;

$\Delta \mathrm{P}$ - calculated pressure difference, $\mathrm{Pa}$, calculated by the formula

$\Delta p=(H-h)(\gamma-\gamma)+0,03 \gamma v^{2} \beta$,

where, $\mathrm{H}$ - building height (from the ground floor level to the top of the exhaust shaft), $m$.

$h_{i}$ - the height from the floor level of the first floor to the middle of the enclosing structure of the i-th floor, for which the calculation is made.

Taken in the middle of the ground floor height, $h_{i}=1,5 \mathrm{~m}$;

$\gamma_{3}, \gamma_{B}$ - specific gravity, respectively, of outdoor and indoor air, $\mathrm{H} / \mathrm{m}^{3}$, calculated by the formula:

$\gamma_{z}=3463 /\left(273+t_{z}\right), \quad \gamma_{i}=3463 /\left(273+t_{i}\right)$,

where $t_{3}$ - calculated outdoor temperature, ${ }^{\circ} \mathrm{C}$, is accepted depending on the temperature zone. Taken for the 1st temperature zone $t_{z}=-$ $22{ }^{\circ} \mathrm{C}$, for II- $\mathrm{t}_{\mathrm{z}}=-19^{\circ} \mathrm{C}$;

$t_{B}$ - the calculated value of the internal air temperature, ${ }^{\circ} \mathrm{C}$, is taken depending on the purpose of the building. Assumed $t_{i}=20^{\circ} \mathrm{C}$;

$v$ - the maximum of the average wind speeds in terms of points for January, $\mathrm{m} / \mathrm{s}$, the frequency of which is $16 \%$ or more;

$\beta_{v}$ - coefficient taking into account the change in air speed along the height of the building.

The scheme of the action of the so-called thermal head due to the temperature difference is shown in Fig. 1. 


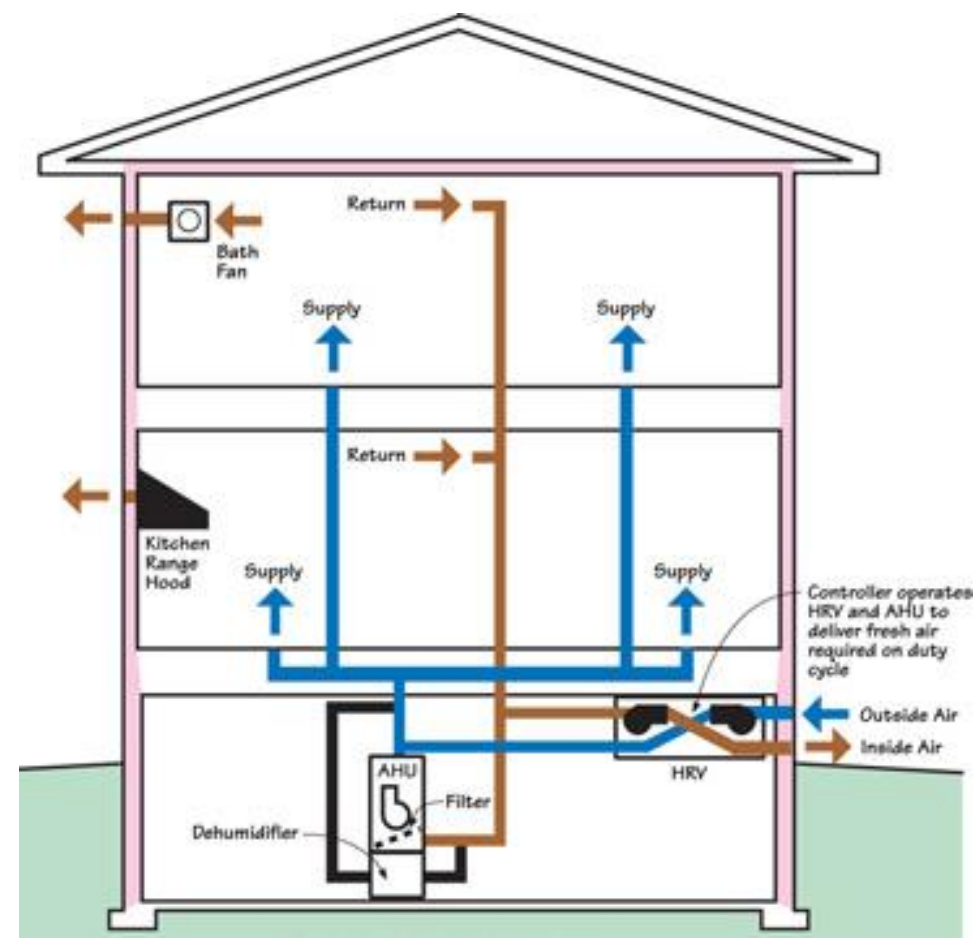

Fig. 1. Thermal head action diagram

Since the lower part of the wall will be the most influential, then according to the diagram of pressure drops in it there will be the maximum temperature head. The wind pressure is listed at this level. For the maximum impact of the wind pressure, territory "A" was chosen, corresponding to the open coast of the sea, lake, reservoir or field. For such a territory, the wind influence will be maximum.

The resistance to air permeability $R_{g}$, which is determined by the method, for this task will consist of the values of the resistances of individual layers of the outer wall, $\mathrm{m}^{2} \mathrm{~h} \mathrm{~Pa} / \mathrm{kg}$, which have the following values:
- Brickwork $120 \mathrm{~mm}$ thick (or $\geq 250 \mathrm{~mm}$ ) - 2 (18)

- $\quad$ Lime plaster $15 \mathrm{~mm}$ thick - 142;

- Plaster on a cement-sand mortar $15 \mathrm{~mm}$ thick - 373;

- Hard mineral wool slabs (regardless of thickness) - 2.

That is, the total resistance to air permeability including the supports of all respective layers. Obviously, the fate of brickwork is noticeably insignificant in comparison with plasters. The resistance to air permeability of the insulation may generally be unaccounted for. 


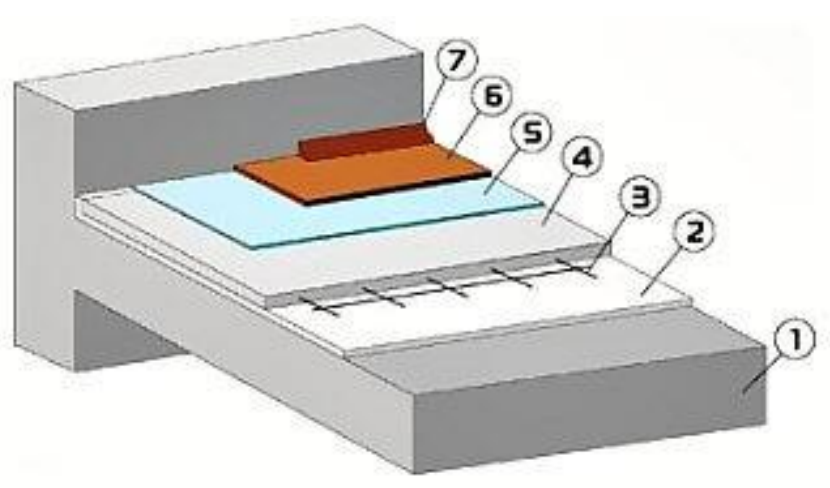

Fig. 2. Energy efficient floor slab

1-Overlap;

2 - Elastic sound insulation for a floating floor;

3 - Mesh for screed reinforcement;

4 - Monolithic screed;

5 - Substrate for the laminate;

6 - Finishing floor covering (laminate); 7 plinth.

For the analysis from the climatic data of the International Association of Engineers, cities were selected according to the values of wind speed from the minimum to the maximum possible in the first and second temperature zones.

The calculated data of the required resistance to air permeability can be exaggerated due to the use of lime, and even with great possibilities, cement-sand plaster. Only for high-rise buildings of about $100 \mathrm{~m}$ should be provided for increased resistance to air permeability, which can be provided by an outer layer of thin-layer plaster cladding.

Similar calculations were performed for two climatic zones with conditional averaged wind speeds equal to $3.5 ; 7.0 ; 11.5 ; 13.0$ and $15 \mathrm{~m} / \mathrm{s}$.
The area of non-compliance with the requirements for air permeability can be analyzed separately, with the choice of additional ways to increase the given values. The possibilities of providing the necessary air permeability in specific design conditions have been analyzed and can be adjusted depending on the height of the building. So the value of $\mathrm{R}_{\text {gn }}$ house $\mathrm{H}=100 \mathrm{~m}$ for the $\mathrm{l}$-th temperature zone at a speed of $15 \mathrm{~m} / \mathrm{s}$ will be only $264.8 \mathrm{~m}^{2}$ $\mathrm{h} \mathrm{Pa} / \mathrm{kg}$.

\section{RESULTS}

The specified solution of the corner joint is traditional and has the same disadvantages as in constructive solutions without insulation from the outside of the wall. Namely, the temperature in the corner is, as expected, lower than the temperature in the main field of the structure and the likely reduced value of the reduced resistance to heat transfer in comparison with the corresponding value in the main field. The value of the temperature drop in the corner and the value of the coefficient of thermal homogeneity should be taken into account when assessing the energy efficiency of the building as a whole and at the stages of checking the sanitary and hygienic 
requirements for individual elements of the house.

Toward analyze the influence of the geometric and heat engineering components of the corner joint of the floor, a brickwork was adopted, it has a wall thickness $\delta_{\text {st }}=0.25 ; 0.38$ and $0.51 \mathrm{~m}$, thermal conductivity $-\lambda_{\mathrm{st}}=0.4 ; 0.6$ and $0.8 \mathrm{~W} /(\mathrm{m} \bullet \mathrm{K})$. insulation has a thickness of $\delta_{t}=0.08 ; 0.12$ and $0.16 \mathrm{~m}$ and thermal conductivity $-\lambda_{\text {st }}=0.04 ; 0.06$ and $0.08 \mathrm{~W} /(\mathrm{m}$ • $\mathrm{K})$. The indicated thicknesses and thermal conductivity correspond to the main generally accepted design solution.

Corner temperature prediction can be based on analytical calculations or numerical simulations. To reduce the number of calculations, a matrix was developed that reduced the number of research options from 45 to 4 .

\section{CONCLUSION}

Consequently, at this stage of the study, an evidence base has been created for ensuring the necessary resistance to air permeability of the internal floor due to layers of plaster and additional external cladding, and a decrease in wall thickness due to cuts for thermal liners located in them does not significantly affect the value of the total resistance to air permeability.

\section{REFERENCES}

1. Sayfiddinov, Sadriddin \& Akhmadiyorov, Ulugbek \& Razzokov, Nurmukhammadkhon \& Akhmedov, Pakhriddin. (2020). OPTIMIZATION OF MODELING WHILE INCREASING ENERGY EFFICIENCY OF BUILDING STRUCTURES OF PUBLIC
BUILDINGS.. Theoretical \& Applied Science. 86. 16-19. 10.15863/TAS.2020.06.86.3.

2. Sayfiddinov Sadriddin.Design of thermal protection of exterior walls of residential buildings. International Journal of Advanced Research in Science, Engineering and Technology Vol. 6, Issue 9 , September 2019.

$\mathrm{pp}$

10946-10949.

Sayfiddinov Sadriddin. Analysis of methods of heat engineering calculations of enclosing walls in Uzbekistan and abroad. Architecture and construction problems (Scientific and technical journal) Samarkand, 2019, №2. pp 57-61.

3. Sayfiddinov Sadriddin, Miralimov Mirakhim Mirmakhmutovich, Makhmudov Said Makhmudovich, Akhmadiyorov Ulugbek Solijonovich. Modern Methods of Increasing Energy Efficiency of Buildings In The Republic Of Uzbekistan at the Design Stage. International Journal of Scientific \& Technology Research Volume 8, Issue 11, November 2019. 1333- 1336 pp. http://www.ijstr.org/final-

print/nov2019/Modern-Methods-OfIncreasing-Energy-Efficiency-Of-BuildingsIn-The-Republic-Of-Uzbekistan-At-TheDesign-Stage.pdf

4. Sayfiddinov Sadriddin. Transfer of heat through protective operated wall structures and their thermophysical calculation for energy efficiency. European Science Review. East West Association for Advanced Studies and Higher Education $\mathrm{GmbH}$-Austria, Vena, Scientific journal № 11122018 (May-June), -pp 79-80

5. Sayfiddinov Sadriddin. Analysis of methods of heat engineering calculations of 
enclosing walls in Uzbekistan and abroad. Architecture and construction problems (Scientific and technical journal) Samarkand, 2019, №2. 57-61 pp.

6. Pirmatov R.Kh., Schipacheva. E.V.,Rashidov J.G. "On peculiarities of formation of the thermal mode in operating panel buildings." International Journal of Scientific and Technology Research 8.10 (2019): 25332535.https://scholar.google.com/scholar?cl uster $=13779299636592450471 \& \mathrm{hl}=$ ru\&as_s $\mathrm{dt}=0,5 \&$ sciodt $=0,5$

7. Pirmatov, Rakhmatilla Khamidullaevich, and Jasur Gayrat Ugli Rashidov. "Research Of The Acoustic Parameters Of Halls And Practical Methods Of Eliminating Acoustic Defects." The American Journal of Engineering and Technology 2.12 (2020): 713.

8. Rashidov, Jasur, et al. "Sound insulation of enclosing structures of buildings and monuments." Theoretical \& Applied Science 2 (2020): 36-38.

9. Pirmatov R. K., Zakharov A.V., Rashidov J. G. Graphical method for calculating sound insulation of air noise of single layer enclosing structures/ International Journal of Advanced Research in Science, Engineering and Technology. Vol. 6, Issue 7, July 2019.Pages 10294- 10298. www.ijarset.com

10. Rashidov, J. "(2017). Sound-insulation technology for ventilated facades, The most urgent issues of the city building and its convergence. Collection of scientific works on the results of Republican scientifictechnical conference. Part 3.10-13 pages, November 10-11." (2017).

11. Rashidov, Jasur. "Measuring sound insulation of air noise." Theoretical \& Applied Science 12 (2019): 121-123.
12. CNR 2.01.04-97 * "Construction heat engineering" Tashkent, 2011.

13. CNR 2.01.18-2000 * Standards for energy consumption for heating, ventilation and air conditioning of buildings and structures. Tashkent, 2011.

14. CRN 23-02-2003 "Thermal protection of buildings" -M.: 2004.

15. CR 23-101-2004 "Design of thermal protection of buildings" - $M$.: 2004 .

16. www.minstroy.uz/constructionrules 